3. Зотеева Н.М., Зимнох-Гузовска Е. Влияние генотипов картофеля на патогенные свойства Phytophthora infestans //Микология и фитопатология. - 2005. T. 39. - №. 1. - С. 59-65.

4. Чалая Н.А., Бирюкова В.А., Киру С.Д. Новые источники устойчивости к золотистой картофельной нематоде (G. rostochiensis Woll.) из коллекции дикорастущих видов картофеля ВИР //Известия Санкт-Петербургского государственного аграрного университета. - 2012. - №. 26. - С. 45-50.

5. Laurila J. et al. Formation of parental-type and novel glycoalkaloids in somatic hybrids between Solanum brevidens and S. tuberosum //Plant Science. - 1996. - T. 118. №. 2. - C. 145-155.

DOI 10.18699/GPB2020-26

\title{
Особенности накопления биофлавоноидов в ягодах интродуцированных сортов винограда на Алтае
}

Ериова И.В., к.б.н., доиент, в.н.с., зав. лабораторией индустриальных технологий, отдел «НИИСС», ФГБНУ Федеральный Алтайский научный иуентр агробиотехнологий, г. Барнаул, Россия.

e-mail:inessers@yandex.ru

В статье представлены результаты исследования содержания биофлавоноидов в ягодах интродуцчированных на Алтае сортов винограда. Установлены суммарное содержание флавоноидов и количество отдельных фракций, зависимость этих показателей от метеоусловий года. Выделень сорта - ценные источники биоантиоксидантов.

Ключевые слова: виноград, сорта, ягоды, биофлавоноиды.

The particularities of bioflavonoid accumulation in the berries of grape varieties introduced in the Altai region

Ershova I.V. Federal Altai Scientific Centre of Agro-Biotechnologies, Barnaul, Russia.

The article discusses the results of the research of bioflavonoid content in the fruits of grape varieties introduced in the Altai region. The total content of flavonoids and the number of separate flavonoid fractions is determined, as well as dependence of these values on weather conditions of the year. The varieties that represent a valuable source of bio-antioxidants are also determined.

Key words: grape, varieties, berries, bioflavonoids.

Ягоды винограда, одной из самых распространенных культур в мире, по праву считаются высокоценным лечебным продуктом питания, сырьем 
для химико-фармацевтической и пищевой промышленности. Они служат источником важнейших биологических компонентов - легкоусвояемых сахаров, органических кислот, макро- и микроэлементов, целого комплекса природных биоантиоксидантов, и в первую очередь - биофлавоноидов. Содержание последних является фактором, в значительной степени определяющим биологическую активность ягод винограда и продуктов его переработки, их лечебный эффект, технологические достоинства сортов [1]. Биофлавоноидам присуща, прежде всего, мощная антиоксидантная активность, позволяющая препятствовать аномальным процессам свободно-радикального окисления и защищать, таким образом, живые организмы от многих патологий. Они обладают противовоспалительными, адаптогенными, капилляроукрепляющими, бактерицидными, нейропротекторными и другими ценными свойствами [2].

Виноград представляет большой интерес для промышленного и любительского садоводства Сибири. Поскольку он являет собой южное, теплолюбивое, незимостойкое растение, долгое время культура считалась неперспективной для региона. С точки зрения его выращивания, климатические условия лесостепной зоны Алтайского края характеризуются недостаточным количеством тепла в период вегетации, не всегда благоприятными условиями перезимовки. Однако в этих условиях успешно вызревают раннеспелые европейские сорта, и на сегодняшний день доказана возможность возделывания укрывной культуры винограда на Алтае. Создание его сортимента осуществляется в основном путем интродукции. К настоящему времени в отделе НИИ садоводства Сибири имени М.А. Лисавенко ФГБНУ ФАНЦА (НИИСС) сформирована и поддерживается ампелографическая коллекция, представленная образцами европейско-азиатской, восточно-азиатской, а также - американской групп. Преобладающее большинство - сорта отечественной селекции столового, технического и универсального назначений. Сортоизучение интродуцированных образцов с целью улучшения сортимента осуществляется по многим направлениям, в том числе - исследование антиоксидантного комплекса свежих ягод винограда. Факторами, определяющими его содержание, являются генетические особенности сорта, условия его произрастания, агротехнические приемы возделывания. Данная работа была направлена на изучение содержания биологически активных фенольных соединений (ФС) - биофлавоноидов в плодах сортов винограда коллекции НИИСС в условиях лесостепной зоны Алтайского края с целью выявления высокоценных в этом отношении сортов.

Исследования проводились в 2013-2016 гг. Объектом изучения являлись зрелые ягоды винограда, выращенного в типичных почвенно-климатических условиях лесостепи Алтайского края. Из обширной коллекции были взяты 13 сортов, зарекомендовавших себя положительно в аспекте проявле- 
ния основных хозяйственно-ценных признаков - Агат Донской, Алешенькин, Восторг, Гуна, Космонавт, Кристалл, Московитянин, Память Лазаревского, Платовский, Сувенир Васьковского, Тамбовский белый, Томайский. Контролем служил универсальный сорт Катыр селекции НИИСС, включенный в Государственный реестр и допущенный к использованию по всем зонам возделывания винограда. Определяли суммарное содержание и фракционный состав биофлавоноидов спектрофотометрическими и колориметрическими методами в этанольных экстрактах плодов.

В результате проведенных исследований был выявлен широкий интервал варьирования показателя содержания биофлавоноидов в ягодах винограда различных сортов, свидетельствующий об очень нестабильном характере накопления этой группы биологически активных веществ (БАВ). Сортовые отличия могли быть четырехкратными, что обусловливалось как особенностями сорта, так и метеоусловиями года, наряду с упомянутыми выше факторами. Поскольку, как было установлено, преобладающей фракцией в составе биофлавоноидов винограда является антоциановый комплекс, существенные различия наблюдались, прежде всего, между сортами с разной окраской плодов. В условиях лесостепи Алтайского края суммарное содержание ФС варьировало в пределах 133,5-728,4 мг/100 г сырой массы (коэффициент вариации V - 42 \%), составляя в среднем 337,3 мг/100 г. Наибольшим накоплением биофлавоноидов в ягодах за годы исследований отличился сорт столового назначения с темноокрашенными ягодами Московитянин - 728,4 мг/100 г (селекции ВНИИГиСПР им. И.В. Мичурина). При этом он был довольно стабильным в проявлении признака (V - 13,5 \%), из года в год выделяясь максимальными среди всех сортов значениями показателя, существенно превышающими контрольные. Столовый сорт селекции этого же института Память Лазаревского, в среднем уступая сорту Московитянин в 1,5 раза, также выделился повышенным содержанием ФС - 486,5 мг/100 г. Максимальное значение показателя, установленное для него, составило 518,4 мг/100 г. Характерной чертой сорта явилась гомеостатичность признака (V - 9,0 \%). В группу перспективных вошли сорта столового назначения с темноокрашенными плодами Агат Донской (селекции ВНИИВиВ им. Я.И. Потапенко) и Космонавт (селекции ВНИИГиСПР) с количеством ФС в ягодах, существенно превышающим средний уровень, от 400 до 600 мг/100 г в разные годы исследования (в среднем - 485,9 и 483,4 мг/100 г соответственно). При этом сорта оказались в значительной степени зависимы от метеофакторов периода вегетации ( $\mathrm{V}>22 \%)$. В одном ряду с упомянутыми стоит и сорт универсального назначения селекции нашего института Катыр с высоким содержанием ФС в ягодах и средней изменчивостью признака ( $\mathrm{V}$ - 16,9 \%). Потенциальные возможности сорта лежат в пределах 600 мг/100 г при среднем показателе 491,2 мг/100 г. Следует отметить сорта технического 
назначения Кристалл и Платовский (селекции ВНИИВиВ), а также - универсальный сорт Гуна (Латвия), с уровнем содержания биофлавоноидов в ягодах, близким к среднему (> 300 мг/100 г), превышающем его в отдельные годы.

Наименьшим количеством ФС в ягодах в условиях Алтая характеризовались столовые сорта со светлоокрашенными плодами Алешенькин (Волгоград) и Восторг (селекции ВНИИВиВ) - до 200 мг/100 г.

Для изученных сортов, по данным дисперсионного анализа, была установлена сильная взаимосвязь содержания ФС и метеофакторов вегетационного периода. Уровень биофлавоноидов в ягодах положительно коррелировал с суммой активных температур (САТ) и отрицательно - с гидротермическим коэффициентом (ГТК) и суммой осадков (СО), что вполне объяснимо с точки зрения биологических особенностей культуры. По накоплению ФС наиболее продуктивным для винограда стал 2015 г. (в среднем - 439,9 мг/100 г), наименее - 2013 г. (в среднем - 307,2 мг/100 г). Последний характеризовался аномально повышенной влажностью воздуха (по данным метеостанции НИИСС), чрезмерным выпадением осадков (428,9 мм), низкой САТ $\left(2043,4{ }^{\circ} \mathrm{C}\right)$ и минимальным количеством ясных дней. Величина ГТК составила 1,96. 2015 г. отличился наибольшей теплообеспеченностью, были отмечены высокое значение САТ $\left(2529,0^{\circ} \mathrm{C}\right)$ с превышением ежемесячных среднемноголетних температур на 2-3 градуса, дефицит осадков по сравнению со среднемноголетним уровнем (232,3 мм), низкий ГТК $-0,91$.

Исследование содержания основных фракций биофлавоноидов в ягодах сортового материала винограда показало преобладание комплекса антоцианов - 77 \% состава, что согласуется с литературными данными, 13,6 \% приходится на долю катехинов, 9,4 \% составляют флавонолы. В наибольшем количестве представлены процианидины, диапазон изменчивости показателя 127,0-385,3 мг/100 г. Содержание антоцианов в зависимости от сорта варьирует в пределах 2,8-292,8 мг/100 г, катехинов - 12,9-111 мг/100 г, флавонолов - 12,2-78,0 мг/100 г. Наиболее ярко различия между сортами выражались в содержании антоцианов, что связано с контрастной окраской плодов. Известно, что именно этой группе биофлавоноидов присуща высокая антиоксидантная активность. К выокоантоциановым можно отнести ягоды сортов Катыр, Агат Донской, Московитянин, Космонавт. Значительное количество фракции Р-активного действия - катехинов - содержалось в плодах сортов Память Лазаревского, Космонавт, Тамбовский белый, Агат Донской, Платовский, Катыр, Гуна.

Резюмируя вышесказанное, хотелось бы отметить, что ягоды интродуцированных на Алтай сортов винограда при благоприятных погодных условиях способны в значительных количествах накапливать биологически активные фенольные соединения, что обусловливает их высокую биологическую ценность. В этом отношении сорта не уступают аналогичным из южных и других регионов, а в ряде случаев и превосходят их. Учитывая тот 
факт, что вышеупомянутые сорта отличаются высокой зимостойкостью, хорошей урожайностью, устойчивостью к болезням и вредителям, крупноплодностью, гармоничным вкусом и ароматом, высокой питательной ценностью, их без сомнения можно признать перспективными для возделывания в условиях Сибири.

\section{Список литературы}

1. Ткаченко М.Г., Соловьева Л.М., Зайцев Г.П., Гришин Ю.В., Мосолкова В.Е., Виноградов Б.А. Фенольный состав и антиоксидантная активность виноградных соков и виноматериалов // «Магарач». Виноградарство и виноделие. - 2012. - № 4. - C. 29-31.

2. Гудковский В.А. Антиокислительный комплекс плодов и ягод и его роль в защите живых систем (человек, растение, плод) от окислительного стресса и заболеваний // Основные итоги и перспективы научных исследований ВНИИСС им. И.В. Мичурина (1931-2001 гг.): Сб. науч. трудов. - Тамбов, 2001. - Т. 1. - С. 76-88.

DOI 10.18699/GPB2020-27

\section{Генетические ресурсы нетрадиционных культур в решении проблем экологической и продовольственной безопасности}

Есимбекова M.A. ${ }^{1 *}$, д.б.н., зав. группь генофонда полевых культур; Еспанов А.М. ${ }^{2}$, директор; Жубанышева А.У. ${ }^{3}$, к.с.-х.н., зав. отд. земледелия; Мукин К.Б. ${ }^{l}$, к.с.-х.н., с.н.с. группь генофонда полевых культур.

${ }^{1}$ ТОО «КазНИИЗиР», п. Алмальбак, Казахстан;

${ }^{2}$ ТОО «ПОСГРР», г. Шалкар, Казахстан;

${ }^{3}$ ТОО «Актюбинская СХОС», г. Актобе, Казахстан.

*e-mail: minura.esimbekova@mail.ru

В статье представлены первичные результаты оценки адаптивной способности и хозяйственной ценности коллекиии дикого кумарчика (Agriophyllum squarrosum L.) в условиях пустьни Северного Приаралья Актюбинской области Казахстана. Установлена возможность селекционного улучшения хозяйственно-ценных признаков в целях одомашнивания.

Ключевые слова: кумарчик, коллекиия, хозяйственно-ценные признаки, кормовая и семенная продуктивность.

\section{Genetic resources of non-traditional crops in solving environmental and food security problems}

Yessimbekova M.A.*, Doctor of Biological Sciences, Head groups of the field crops gene pool, “KazRIAPG” LLP, Almalybak, Kazakhstan,; Espanov AM., Director of "PESPGR" LLP, Shalkar, Kazakhstan; Zhubanysheva A.У., Candidate 